\title{
Effect of Storage Temperature on pH and Conductivity of Reverse Osmosis Water Treated with Atmospheric Plasma
}

\author{
F.R. Figueira, ${ }^{a, *}$ A.C.O.C. Doria, ${ }^{a}$ S. Khouri, ${ }^{a}$ H.S. Maciel, ${ }^{b}$ R.S. Pessoa, ${ }^{b}$ \\ \& M.A.R. Ramos ${ }^{a}$ \\ aUniversidade do Vale do Paraíba/IP\&D/Laboratório de Biotecnologia e Plasmas Elétricos, São \\ José dos Campos, SP, 12244-000, Brazil; ' Instituto Tecnológico de Aeronáutica/Departamento \\ de Física, São José dos Campos, SP, 12228-900, Brazil \\ *Address all correspondence to: F.R. Figueira, Universidade do Vale do Paraíba/IP\&D/Laboratório de Biotecnologia \\ e Plasmas Elétricos, São José dos Campos, SP, 12244-000, Brazil; Tel.: +55 (12) 3947-1142, Fax: +55 (12) 3947- \\ 1142,E-mail: ferfig510@gmail.com
}

\begin{abstract}
We believe that the reactions involved in plasma-activated water (PAW) production are a consequence of long-lived reactive oxygen and nitrogen species (e.g., $\mathrm{NO}, \mathrm{O}, \mathrm{OH}$, $\mathrm{ONOO}^{-}$, and $\mathrm{H}_{2} \mathrm{O}_{2}$ ) that are transferred from the plasma environment to liquid. Based on the assumption of reaction continuity in water treated with atmospheric plasma, we devised an experiment to monitor $\mathrm{pH}$ and electrical conductivity in samples of reverse osmosis water, before and after treatment. We used gliding arc discharge that was operated by a mixture of air + humid air at a flow of $10 \mathrm{~L} / \mathrm{min}$ to evaluate the continuation of these chemical reactions at different storage temperatures: room temperature $\left(24^{\circ} \mathrm{C}\right)$ for group 1 and refrigeration temperature $\left(3^{\circ} \mathrm{C}\right)$ for group 2. To obtain PAW, we treated three 250-mL samples of reverse osmosis water for 10 , 20, and $30 \mathrm{~min}$ of exposure to the plasma. After treatment, we performed periodic monitoring of the samples, with $24 \mathrm{~h}$ among measurements for a total period of $96 \mathrm{~h}$. We can conclude that with increasing treatment time, acidification and electrical conductivity of water also increase. At this experiment range, storage temperature did not to exert significant influence on PAW physicochemical properties.
\end{abstract}

KEY WORDS: plasma-activated water, gliding arc, types of water

\section{INTRODUCTION}

Discharges in contact with or immersed in liquids are a rich source of highly oxidative and reductive radicals that provide a sustainable level of reactivity. Such discharges, consequently, induce chemical changes in the aqueous medium including decreased $\mathrm{pH}$ and strong oxidizing action. ${ }^{1-3}$ The technique that produces plasma-activated water $(\mathrm{PAW})^{4}$ has gained importance in decontamination and disinfection. ${ }^{5,6}$ Reactive oxygen and nitrogen species (RONS) that are generated in the plasma are transported in the liquid medium by convection and diffusion. ${ }^{7}$ According to Verlackt et al., ${ }^{7}$ the dissolved species accumulate in an inverse vortex at the plasma-liquid interface and are then transported through the superficial to deepest layers of the liquid medium. RONS that are considered to be representative of oxidative reactions are hydrogen peroxide $\left(\mathrm{H}_{2} \mathrm{O}_{2}\right)$, nitrite $\left(\mathrm{NO}_{2}^{-}\right)$, and nitrate $\left(\mathrm{NO}_{3}^{-}\right){ }^{8}$ 
The complexity of PAW was first pointed out by Traylor et al., ${ }^{9}$ who concluded that the multiple chemical components present in PAW may exert different biological effects at different time scales. The authors corroborated this by concluding that to affect concentration of long-lived species, the chemistry involved needed longer time scales. They observed that short-lived species, that is, $\mathrm{OH}, \mathrm{NO}_{2}$, and $\mathrm{NO}_{3}$, undergo significantly decreased densities every $1 \mathrm{~mm}$ at the plasma-liquid interface and are completely consumed in the liquid's lower layers. Other species, including $\mathrm{H}_{2} \mathrm{O}_{2}, \mathrm{HNO}_{2} / \mathrm{NO}_{2}^{-}, \mathrm{NO}_{3}^{-}$, $\mathrm{HO}_{2} / \mathrm{O}_{2}^{-}, \mathrm{O}_{3}$, and $\mathrm{ONOOH} / \mathrm{ONOO}^{-}$, remain at their relatively constant densities as a function of greater interface distance. ${ }^{7}$

Storage conditions may also influence action time of PAW. Shen et al. ${ }^{10}$ evaluated antimicrobial activity of PAW stored at different temperatures and found that PAW stored at $-80^{\circ} \mathrm{C}$ maintained its bactericidal activity, unlike others that were stored at $25^{\circ} \mathrm{C}, 4^{\circ} \mathrm{C}$, and $-20^{\circ} \mathrm{C}$, for which antimicrobial action decreased. On the basis of these findings, our objective was to monitor $\mathrm{pH}$ and electrical conductivity of reverse osmosis water samples after treatment with atmospheric plasma at different storage temperatures.

\section{MATERIALS AND METHODS}

\section{A. Gliding Arc Reactor and Treatment Conditions}

To obtain PAW, samples containing $250 \mathrm{~mL}$ reverse osmosis water (we used a $20 \mathrm{M} \Omega$, OS 20 LXE) (Gehaka; São Paulo, Brazil) were exposed to plasma for different periods of time. Treatment groups were designated as control (without treatment) and treated. The treatment group varied in plasma exposure time of $\sim 10$ (T10), 20 (T20), and 30 (T30) min. We used a gliding arc type of reactor, previously described in studies by Doria et al. ${ }^{11}$ and Simomura et al. ${ }^{12}$ For treatments, we used gas composed of a mixture of compressed air (using the medical odontological compressor MSV 6/30) (Schulz SA; São Paulo, Brazil) that we passed through a Büchner flask containing deionized water. Flow rate was $10 \mathrm{~L} / \mathrm{min}$, and all treatment was performed in the discharge region. Figure 1 illustrates the treatment scheme.

\section{B. pH and Conductivity}

A properly calibrated $\mathrm{pH}$ meter (Q402M, QUIMIS; São Paulo, Brazil) was used for $\mathrm{pH}$ measurements (measurement range was from 0.00 to $14.00 \mathrm{pH}$, and a $+2000-\mathrm{mV}$ absolute) and conductivity (reading range was from $2 \mu \mathrm{S} / \mathrm{cm}$ to $\sim 10.00 \mathrm{mS} / \mathrm{cm}$ ) during a period of $96 \mathrm{~h}$. To identify instantaneous effects of treatment, measurements were performed immediately before and after treatment and afterwards, with periodic monitoring at a 24 -h intervals among measurements.

\section{Storage}

The samples were divided into two groups and subjected to two storage temperatures: room temperature $\left(24^{\circ} \mathrm{C}\right)$ and refrigerated temperature $\left(3^{\circ} \mathrm{C}\right)$. Vials were packed with 


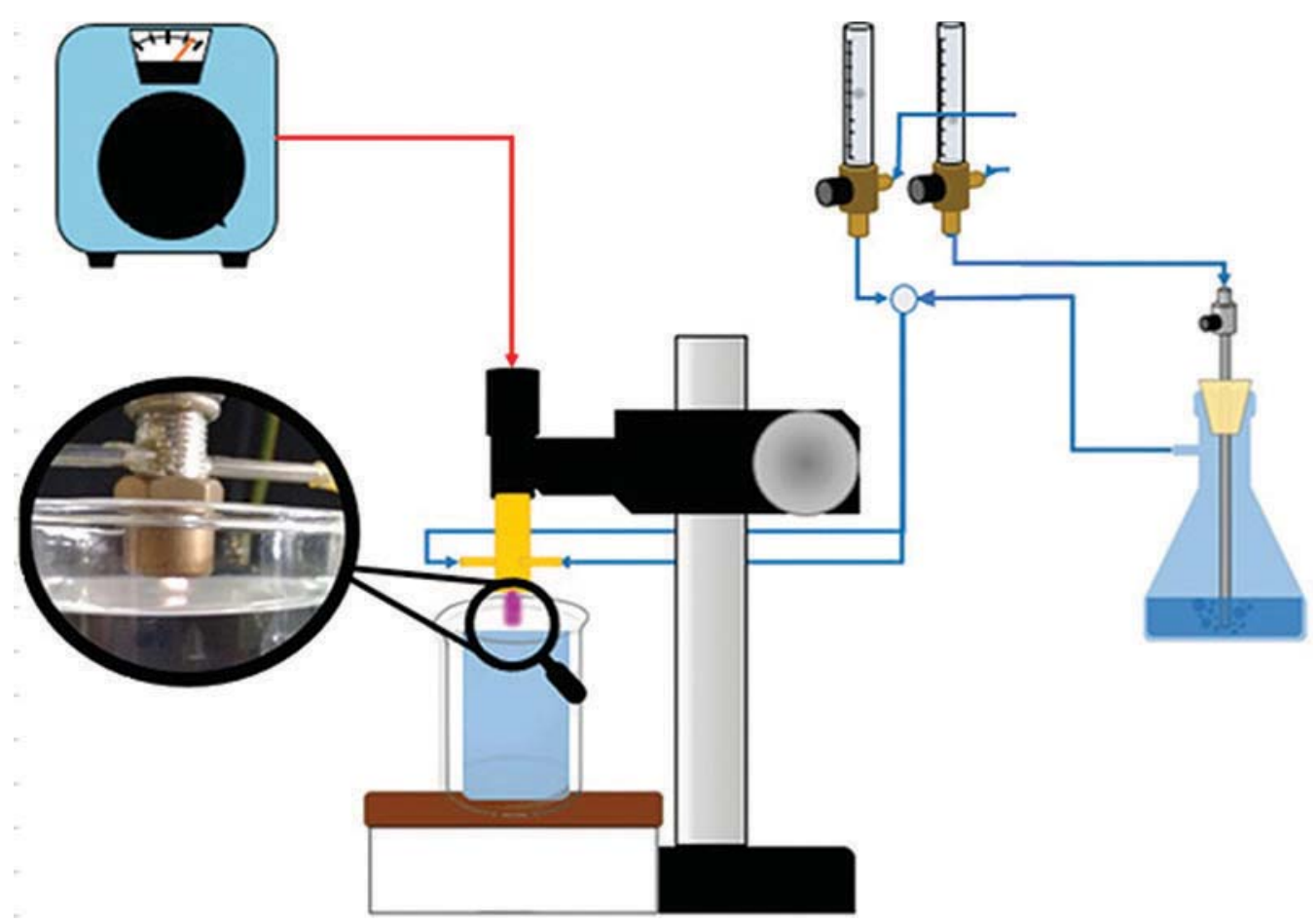

FIG. 1: Sample treatment scheme

aluminum foil to ensure that samples were only exposed to plasma discharge and no other source of energy.

\section{Statistical Analysis}

Statistical analyses were carried out using analysis of variance (ANOVA), using R software, version 3.2.3 (R Foundation for Statistical Computing).

\section{RESULTS}

Results obtained after treatment and during subsequent storage for $96 \mathrm{~h}$ are shown in Table 1. Behavior of groups during the 24-h periodic monitoring is presented in Fig. 2. ANOVA results are shown in Fig. 3.

When evaluating how group $\mathrm{pH}$ and conductivity were affected at the end of the experiment (Table 1), we found that storage temperature did not seem to exert a significant influence. However, periodic monitoring during the $96 \mathrm{~h}$ of storage (Fig. 2) indicated that $\mathrm{pH}$ during the $48-72-\mathrm{h}$ storage interval tended to return to a neutral $\mathrm{pH}$. This is most evident in the T20 group, in which the refrigerated temperature $\left(3^{\circ} \mathrm{C}\right)$ seemed to accentuate this behavior.

Volume 8, Issue 3, 2018 
TABLE 1: Averages of $\mathrm{pH}$ and conductivity after $96 \mathrm{~h}$ of storage

\begin{tabular}{|l|c|c|c|c|c|c|c|c|}
\hline & \multicolumn{2}{|c|}{ Control } & \multicolumn{2}{c|}{ T10 } & \multicolumn{2}{c|}{ T20 } & \multicolumn{2}{c|}{ T30 } \\
\hline Average & $\mathbf{p H}$ & $\boldsymbol{\mu S}$ & $\mathbf{p H}$ & $\boldsymbol{\mu S}$ & $\mathbf{p H}$ & $\boldsymbol{\mu S}$ & $\mathbf{p H}$ & $\boldsymbol{\mu S}$ \\
\hline Stored at $24^{\circ} \mathrm{C}$ & 6.96 & 10.8 & 6.49 & 19.42 & 5.50 & 26.41 & 6.37 & 309.14 \\
\hline Stored at $3^{\circ} \mathrm{C}$ & 6.71 & 11.08 & 6.15 & 19.47 & 6.13 & 27.53 & 6.24 & 134.30 \\
\hline
\end{tabular}

T10, $10 \mathrm{~min}$; T20, $20 \mathrm{~min}$; T3: $30 \mathrm{~min}$.

Regarding conductivity, treated groups followed the control variable, and only the T30 group showed a behavioral difference. It should be noted that the sudden increase in conductivity at $72 \mathrm{~h}$ of storage at room temperature was due to the isolated result of one of the samples, for which the specific value reached $642 \mu \mathrm{S} / \mathrm{cm}^{2}$. Because this value was quite discrepant from previous and subsequent results, we concluded that it was likely an outlier.

ANOVA results in Fig. 3 reveal the significance of factors including treatment, storage time (Tp), and storage temperature (Tt) on $\mathrm{pH}$ and conductivity, including the possible interaction among these factors, with two-to-two interaction and all three together, as follows: T:Tp, interaction between treatment and time after treatment; T:Tt, interaction between treatment and temperature; $\mathrm{Tp}$ : Tt, interaction between time after treatment and temperature; and T:Tp:Tt, interaction among the three factors.
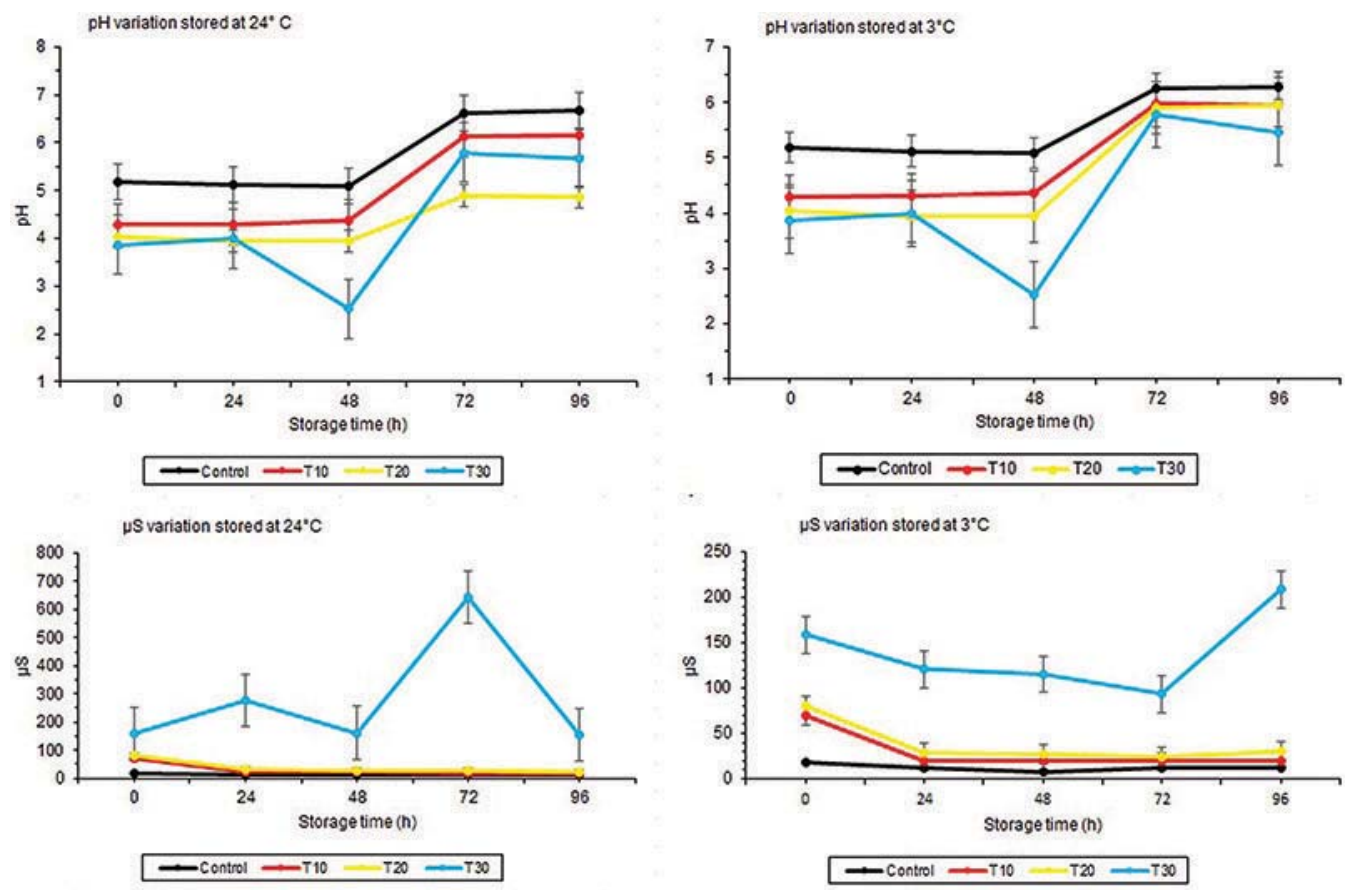

FIG. 2: $\mathrm{pH}$ and $\mu \mathrm{S}$ variation with storage at $24^{\circ} \mathrm{C}$ and $3^{\circ} \mathrm{C}$ 


\begin{tabular}{|c|c|c|c|c|c|c|c|c|c|c|c|}
\hline \multicolumn{6}{|c|}{ > ANOVA pH (T10min) } & \multicolumn{6}{|c|}{$>$ ANOVA $\mu \mathrm{S}$ (T10min) } \\
\hline & Df & Sum $\mathrm{Sq}$ & Mean Sq & F value & $\operatorname{Pr}(>\mathrm{F})$ & & Df & Sum $\mathrm{Sq}$ & Mean Sq & F value & $\operatorname{Pr}(>\mathrm{F})$ \\
\hline T10 & 1 & 2.765 & 2.765 & 16.978 & $0.000156^{* * *}$ & $\mathrm{~T} 10$ & 1 & 3.662 & 3.662 & 20.552 & $0.000853 * * *$ \\
\hline Tpl & 1 & 10.683 & 10.683 & 65.591 & $2.12 \mathrm{e}-10^{* * *}$ & Tpl & 4 & 16 & 4 & 0.023 & \begin{tabular}{|l|}
0.998801 \\
\end{tabular} \\
\hline Tt1 & 1 & 0.408 & 0.408 & 2.508 & 0.120135 & $\mathrm{Tt1}$ & 1 & 181 & 181 & 1.017 & 0.33488 \\
\hline Tl0:Tpl & 1 & 0.090 & 0.090 & 0.555 & 0.459928 & T10:Tpl & $\cdot$ & $\cdot$ & $\cdot$ & $\cdot$ & $\cdot$ \\
\hline T10:Tt1 & 1 & 0.090 & 0.090 & 0.551 & 0.461834 & T10:Itl & 1 & 66 & 66 & 0.372 & 0.554517 \\
\hline Ipl:Ttl & 1 & 2.150 & 2.150 & 13.203 & $0.000702^{* * *}$ & Tpl:Ttl & 3 & 12 & 4 & 0.023 & 0.995064 \\
\hline Tl0:Tpl & 1 & 0.067 & 0.067 & 0.411 & 0.524561 & T10:Tpl & - & - & - & $\cdot$ & - \\
\hline Residuals & 46 & 7.492 & 0.163 & & & Residuals & 11 & 1.960 & 178 & & \\
\hline \multicolumn{6}{|c|}{ > ANOVA pH (T20min) } & \multicolumn{6}{|c|}{$>$ ANOVA $\mu \mathrm{S}(\mathrm{T} 20 \mathrm{~min})$} \\
\hline & Df & Sum Sq & Mean Sq & F value & $\operatorname{Pr}(>\mathrm{F})$ & & Df & Sum Sq & Mean Sq & F value & $\operatorname{Pr}(>\mathrm{F})$ \\
\hline $\mathrm{T} 20$ & 1 & 11.929 & 11.929 & 143.814 & $9.28 \mathrm{e}-16^{* * *}$ & $\mathrm{~T} 20$ & 1 & 6.798 & 6.798 & 38.149 & $6.94 e-05 * * *$ \\
\hline Tp2 & 1 & 13.246 & 13.246 & 159.698 & $<2 e-16^{* * *}$ & Tp2 & 4 & 47 & 12 & 0.066 & 0.991 \\
\hline $\mathrm{T}+2$ & 1 & 0.668 & 0.668 & 8.057 & $0.00672 * *$ & $\mathrm{Tt} 2$ & 1 & 126 & 126 & 0.708 & 0.418 \\
\hline T20:Tp2 & 1 & 0.451 & 0.451 & 5.441 & $0.02410^{*}$ & T20:Tp2 & - & - & - & $\cdot$ & $\cdot$ \\
\hline $\mathrm{T} 20: \mathrm{Tt2}$ & 1 & 3.084 & 3.084 & 37.179 & $2.07 \mathrm{e}-07 * * *$ & $\mathrm{~T} 20: \mathrm{Tt} 2$ & 1 & 103 & 103 & 0.575 & 0.464 \\
\hline $\mathrm{Tp} 2: \mathrm{Tt2}$ & 1 & 2.234 & 2.234 & 26.934 & $4.64 \mathrm{e}-06 * * *$ & $\mathrm{Tp2}: \mathrm{Tt2}$ & 3 & 88 & 29 & 0.165 & 0.917 \\
\hline T20:Tp2: & 1 & 0.082 & 0.082 & 0.993 & 0.32416 & T20:Tp2: & - & - & - & $\cdot$ & $\cdot$ \\
\hline Residuals & 46 & 3.815 & 0.083 & & & Residuals & 11 & 1.960 & 178 & & \\
\hline \multicolumn{6}{|c|}{ > ANOVA pH (T30min) } & \multicolumn{6}{|c|}{$>$ ANOVA $\mu \mathrm{S}(\mathrm{T} 30 \mathrm{~min})$} \\
\hline & Df & Sum Sq & Mean Sq & F value & $\operatorname{Pr}(>\mathrm{F})$ & & Df & Sum Sq & Mean Sq & F value & $\operatorname{Pr}(>\mathrm{F})$ \\
\hline T30 & 1 & 4.267 & \begin{tabular}{|l|}
4.267 \\
\end{tabular} & 15.520 & $0.000275^{* * *}$ & $\mathrm{~T} 30$ & 1 & 216.830 & 216.830 & 1.216 .753 & $1.29 \mathrm{e}-12 \ldots * *$ \\
\hline Tp3 & 1 & 25.982 & 25.982 & 94.495 & $9.94 \mathrm{e}-13 * * *$ & Tp3 & 4 & 155.961 & 38.990 & 218.797 & $2.11 \mathrm{e}-10 * * *$ \\
\hline $\mathrm{Tt} 3$ & 1 & 0.115 & 0.115 & 0.418 & 0.521168 & $\mathrm{Tt3}$ & 1 & 166 & 166 & 0.934 & 0.354604 \\
\hline T30:Tp3 & 1 & 4.535 & 4.535 & 16.493 & $0.000188 * * *$ & T30:Tp3 & - & - & - & $\cdot$ & $\cdot$ \\
\hline $\mathrm{T} 30: \mathrm{Tt} 3$ & 1 & 0.359 & 0.359 & 1.307 & 0.258778 & T30:Tt3 & 1 & 5.804 & 5.804 & 32.570 & $0.000137^{* * *}$ \\
\hline Tp3:Tt3 & 1 & 0.767 & 0.767 & 2.790 & 0.101675 & $\mathrm{Tp} 3: \mathrm{Tt3}$ & 3 & 253.725 & 84.575 & 474.598 & $6.52 \mathrm{e}-12^{* * * *}$ \\
\hline T30:Tp3: & 1 & 0.110 & 0.110 & 0.401 & 0.529953 & T30:Tp3. & - & $\cdot$ & $\cdot$ & $\cdot$ & - \\
\hline Residuals & 46 & 12.648 & 12.648 & & & Residuals & 11 & 1.960 & 178 & & \\
\hline \multicolumn{12}{|c|}{ 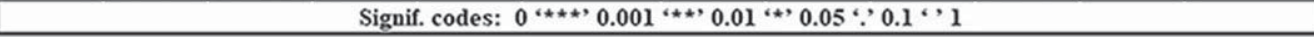 } \\
\hline
\end{tabular}

FIG. 3: ANOVA results. Tp, Storage time; Tt, storage temperature

\section{DISCUSSION}

For the groups treated in the present study, ANOVA results produced evidence that treatment time was a statistically significant factor for both $\mathrm{pH}$ and conductivity. Storage time was significant for $\mathrm{pH}$ in all treatments, but conductivity was only significant for $\mathrm{T} 30$ treatment. Storage temperature was significant for $\mathrm{pH}$ in T20 treatment, but this did not produce a perceptible influence on conductivity.

Regarding the effect of interaction of two factors together, we observed that $\mathrm{pH}$ was not only affected by interaction of storage time and temperature, but also by interaction between treatment and storage time. Conductivity was affected by interactions only in the T30 treatment, in which an interaction between treatment and temperature was found as well as time and storage temperature.

With periodic monitoring (Fig. 2) immediately after treatment (time 0), it is possible to infer a direct relationship of proportionality between a reduction in $\mathrm{pH}$ and an increase in conductivity with time of exposure to plasma. This relationship has already been reported in studies with other plasma devices, with some summarized in Table 2.

Volume 8, Issue 3, 2018 
TABLE 2: $\mathrm{pH}$ and conductivity of different plasma devices used to make PAW

\begin{tabular}{|l|c|c|c|c|}
\hline Discharge type & Treatment time & pH & Conductivity & Ref. \\
\hline \multirow{2}{*}{ Cylindrical double DBD } & $15 \min$ & $3.65 \pm 0.01$ & $32 \pm 1 \mu \mathrm{S} / \mathrm{cm}$ & \multirow{2}{*}{13} \\
\cline { 2 - 4 } & $30 \min$ & $3.15 \pm 0.01$ & $75 \pm 2 \mu \mathrm{S} / \mathrm{cm}$ & \\
\hline$\mu$-Jet & $0-50 \min$ & 2 & $1200 \mu \mathrm{S} / \mathrm{cm}$ & \multirow{2}{*}{14} \\
\cline { 1 - 4 }$\mu$-Arc & $0-50 \min$ & 2 & $2000 \mu \mathrm{S} / \mathrm{cm}$ & \\
\hline \multirow{2}{*}{ Plasma jet } & $10 \min$ & 3 & $350 \mu \mathrm{S} / \mathrm{cm}$ & \multirow{2}{*}{15} \\
\cline { 2 - 4 } & $20 \min$ & 3 & $450 \mu \mathrm{S} / \mathrm{cm}$ & \\
\hline
\end{tabular}

DBD, Dielectric-barrier discharge; PAW, plasma-activated water.

Increased conductivity and decreased $\mathrm{pH}$ are evidence of the accumulation of active ions in PAW. ${ }^{13}$ According to Vlad and Anghel, ${ }^{14}$ electrical conductivity and $\mathrm{pH}$ are dependent on the concentration of nitric acid in the water. These authors compared $\mathrm{pH}$ and electrical conductivity of the treated water with the plasma, using the $\mathrm{pH}$ and electrical conductivity of a solution of $\mathrm{HNO}_{3}$. They noticed that both the $\mathrm{HNO}_{3}$ solution and the treated water had similar values within the error range of the measurements. They suggested that both effects were caused by acidification, and increased electrical conductivity was due to the formation of $\mathrm{NO}_{3} / \mathrm{HNO}_{3}$ in water exposed to plasma. ${ }^{14}$

However, ANOVA also showed differences in influences of the other factors on the treated groups. For the $\mathrm{T} 10$ group, significant factors affecting $\mathrm{pH}$, in addition to the time of treatment, included time after treatment (Tp1) and the interaction of two to two: time after treatment and temperature (Tp1:Tt1). If we compare with the results shown in Fig. 2, we can see that for up to $48 \mathrm{~h}$, the T10 group presented the most linear $\mathrm{pH}$ of the treated groups. However, after $72 \mathrm{~h}$ of storage, the $\mathrm{pH}$ returned to neutral, a more pronounced characteristic when stored at refrigerated temperature. This supports the significance of the interaction Tp1:Tt1.

For the 20-min group, in addition to the factors that also influenced the 10-min group, storage temperature ( $\mathrm{Tt} 2)$ and its respective interactions were significant. The difference in $\mathrm{pH}$ behavior in groups stored at room temperature and those that were refrigerated is very evident (Fig. 2), because in the first condition, the variation for neutrality with $72 \mathrm{~h}$ is minimal. This is dissimilar to what is shown in the second condition, in which the $\mathrm{pH}$ of T20 arrives to the same value as that of T10. Finally, for T30, time after treatment (Tp3) and the respective interaction with treatment (T30:Tp3) were more significant. In $48 \mathrm{~h}$ of storage, $\mathrm{pH}$ became more acidic and then returned to neutral. It is possible that this difference was a consequence of the outlier sample that also influenced conductivity behavior. 


\section{CONCLUSIONS}

Statistical analyses showed that in addition to treatment time, other factors influenced $\mathrm{pH}$ and conductivity of the samples subjected to plasma, and each factor contributed differently throughout the storage period. Monitoring the control group together with the treated groups showed a tendency to return from a more acidic to a neutral $\mathrm{pH}$ that is intrinsic to water. However, exposure to plasma caused treated groups to exhibit differences in $\mathrm{pH}$ levels over time and at the end of the experiment. A suggestion for future studies is to quantify the concentration of these long-lived reactive species in the water and assess whether storage factors may interfere with species production and consequent concentration.

\section{ACKNOWFDGMENT}

This work was supported by PROSUC-CAPES-Univap and FAPESP (Grant No. 2015/ 10876-6).

\section{REFERENCES}

1. Bruggeman PJ, Kushner MJ, Locke BR, Gardeniers JGE, Graham WG, Graves DB, Hofman-Caris RCHM, Maric D, Reid JP, Ceriani E, Fernandez Rivas D, Foster JE, Garrick SC, Gorbanev Y, Hamaguchi S, Iza F, Jablonowski H, Klimova E, Kolb J, Krcma F, Lukes P, Machala Z, Marinov I, Mariotti D, Mededovic Thagard S, Minakata D, Neyts EC, Pawlat J, Petrovic ZLj, Pflieger R, Reuter S, Schram DC, Schröter S, Shiraiwa M, Tarabová B, Tsai PA, Verlet JRR, von Woedtke T, Wilson KR, Yasui K, Zvereva G. Plasma-liquid interactions: A review and roadmap. Plasma Sources Sci Technol. 2016 Sep 30;25(5):053002.

2. Lukes P, Dolezalova E, Sisrova I, Clupek M. Aqueous-phase chemistry and bactericidal effects from an air discharge plasma in contact with water: Evidence for the formation of peroxynitrite through a pseudo-second-order post-discharge reaction of $\mathrm{H}_{2} \mathrm{O}_{2}$ and $\mathrm{HNO}_{2}$. Plasma Sources Sci Technol. 2014 Feb 4;23(1):015019.

3. Oehmigen K, Hähnel M, Brandenburg R, Wilke C, Weltmann K-D, von Woedtke T. The role of acidification for antimicrobial activity of atmospheric pressure plasma in liquids. Plasma Proc Polym. 2010 Mar 22;7(3-4):250-7.

4. Brisset J-L, Moussa D, Doubla A, Hnatiuc E, Hnatiuc B, Kamgang Youbi G, Herry JM, Naïtali $\mathrm{M}$, Bellon-Fontaine MN. Chemical reactivity of discharges and temporal post-discharges in plasma treatment of aqueous media: Examples of gliding discharge treated solutions. Ind Eng Chem Res. 2008 Aug;47(16):5761-81.

5. Joshi RP, Thagard SM. Streamer-like electrical discharges in water: Part II. Environmental applications. Plasma Chem Plasma Proc. 2013 Feb 20;33(1):17-49.

6. Brisset J-L, Benstaali B, Moussa D, Fanmoe J, Njoyim-Tamungang E. Acidity control of plasmachemical oxidation: Applications to dye removal, urban waste abatement and microbial inactivation. Plasma Sources Sci Technol. 2011 Jun 1;20(3):034021.

7. Verlackt CCW, Van Boxem W, Bogaerts A. Transport and accumulation of plasma generated species in aqueous solution. Phys Chem Chem Phys. 2018;20(10):6845-59.

8. Jablonowski H, von Woedtke T. Research on plasma medicine-relevant plasma-liquid interaction: What happened in the past five years? Clin Plasma Med. 2015 Dec;3(2):42-52.

9. Traylor MJ, Pavlovich MJ, Karim S, Hait P, Sakiyama Y, Clark DS, Graves DB. Long-term antibacterial efficacy of air plasma-activated water. J Phys D Appl Phys. 2011 Nov 30;44(47):472001.

Volume 8, Issue 3, 2018 
10. Shen J, Tian Y, Li Y, Ma R, Zhang Q, Zhang J, Fang J. Bactericidal effects against S. aureus and physicochemical properties of plasma activated water stored at different temperatures. Sci Rep. 2016 Sep 27;6(1):28505.

11. Doria ACOC, Sorge C di PC, Santos TB, Brandão J, Gonçalves PAR, Maciel HS, Khouri S, Pessoa RS. Application of post-discharge region of atmospheric pressure argon and air plasma jet in the contamination control of Candida albicans biofilms. Res Biomed Eng. 2015 Dec;31(4):358-62.

12. Simomura LS, Doria ACOC, Figueira FR, Redi GTC, Lima JSB, Maciel HS, Khouri S, Pessoa RS. Action of an argon/water vapor plasma jet in the sterilization of silicone contaminated with Candida albicans. Plasma Med. 2017;7(3):299-311.

13. Sivachandiran L, Khacef A. Enhanced seed germination and plant growth by atmospheric pressure cold air plasma: Combined effect of seed and water treatment. RSC Adv. 2017;7(4):1822-32.

14. Vlad I-E, Anghel SD. Time stability of water activated by different on-liquid atmospheric pressure plasmas. J Electrostat. 2017 Jun;87:284-92.

15. Ma R, Wang G, Tian Y, Wang K, Zhang J, Fang J. Non-thermal plasma-activated water inactivation of food-borne pathogen on fresh produce. J Hazard Mater. 2015 Dec;300:643-51. 